\title{
The Attitude Of Non- English Major Student In Learning English
}

\author{
Supiah $^{1}$ \\ ${ }^{1}$ Institut Syaikah Abdurrahman Siddik Bangka Belitung1
}

\begin{tabular}{|c|c|c|}
\hline \multicolumn{2}{|c|}{ Info Artikel : } & "ABSTRAK \\
\hline $\begin{array}{l}\text { Diterima } \\
\text { Direvisi } \\
\text { Dipublish }\end{array}$ & $\begin{array}{l}: 17 \text { Februari } 018 \\
: 23 \text { Maret } 2018 \\
: 15 \text { April } 2018\end{array}$ & $\begin{array}{l}\text { Tulisan ini menganalisis hasil dari survei terhadap } 116 \text { siswa utama non- } \\
\text { Inggris dari empat jurusan di IAIN Syaikh Abdurrahman Siddik Bangka } \\
\text { Belitung. Berfokus pada beberapa penyebab yang mungkin menghambat } \\
\text { pembelajaran bahasa Inggris di masa lalu bagi siswa yang berpartisipasi } \\
\text { dalam survei, dan perspektif siswa tentang pembelajaran bahasa Inggris di di } \\
\text { IAIN Syaikh Abdurrahman Siddik Bangka Belitung Syaikh Abdurrahman } \\
\text { Siddik Bangka Belitung. Dalam studi yang dilaporkan di sini, Kuisioner } \\
\text { yang dipakai dari Hsiu-Ju Lin dan A. Clyde Warden tentang Pembelajaran } \\
\text { Bahasa Inggris terbuka, Faktor-faktor pembelajaran Bahasa Inggris untuk } \\
\text { populasi ini dianalisis secara deskriptif. Hasil penelitian menunjukkan bahwa } \\
\text { sebagian besar siswa tidak memiliki rasa takut atau perasaan tidak } \\
\text { menyenangkan tentang pengalaman belajar bahasa Inggris mereka di masa } \\
\text { lalu dan para siswa dari jurusan yang berbeda memiliki perspektif yang } \\
\text { berbeda tentang pembelajaran bahasa Inggris. Beberapa saran disediakan } \\
\text { untuk aplikasi masa depan dalam mengajar Bahasa Inggris ke jurusan non- } \\
\text { Inggris di IAIN Syaikh Abdurrahman Siddik Bangka Belitung }\end{array}$ \\
\hline
\end{tabular}

\section{Kata Kunci \\ Sikap \\ Bukan Mahasiswa Bahasa Inggris}

Keyword :

Attitude

Non English Major Student Learning English

\begin{abstract}
ABSTRAC
This paper analyzed the results from a survey of 116 non English major students from four majors at State College for Islamic Studies, Syaikh Abdurrahman Siddik Bangka Belitung. It focused on some causes that may have hindered English learning in the past for students participating in the survey, and the students' perspectives about English learning in State College for Islamic Studies, Syaikh Abdurrahman Siddik Bangka Belitung.. In the study reported here, a ready-made questionnaire from HsiuJu Lin dan A. Clyde Warden about The English Learning Questionnaire was exposed, Factors of English learning for this population were analyzed descriptively. Results showed that most of the students had not either fear or unpleasant feelings about their past English learning experiences, and those students of different majors had different perspectives about English learning. Several suggestions are provided for future application in teaching English to non-English majors at State College for Islamic Studies, Syaikh Abdurrahman Siddik Bangka Belitung..
\end{abstract} (https://creativecommons.org/licenses/by/4.0/)

\author{
Koresponden: \\ Supiah, \\ Email: Supiahwagiyo@gmail.com
}

\section{Introduction}

English learned at all levels of education, start elementary school until college (Echevarria, Short, \& Powers, 2006). This is due to the mastery of the English language an important needs along with the rapid development of science and technology and the demands of quality resources and increase the quality of human resources is also directly related to the improvement of English language learning that includes many aspects(Butler \& Iino, 2005).

During this the issues regarding the improvement of the results of learning English more focused to the teaching of the Bible, the theory of learning language, lesson materials, approaches and teaching methodologies, design syllabus, etc. (Byram \& Hu, 2013). Although a lot of research done regarding this but most research was done based on assumptions of Western culture (Hatch, 2002). Still a little research that leads to the topic of how local education or teaching environment affecting student learning nonEnglish where English language is a compulsory courses taken in accordance with the existing curriculum and also because the needs of professional(Helsby \& McCulloch, 2002). 
This can be seen from seeing people especially parents to equip our children with the knowledge and skills to communicate, especially English-language skills with their child to the formal education institutions or informal any that can help their children in improving English skills(Brock-Utne, 2001).

This shows that there is a high level of motivation from the students and parents to achieve skill in English although the factors may vary. For some of the students learning English gives them the opportunity to expand for association. The students of high school students and college students basically constituted to get the work. Some of the other students have confidence that their future will be better if they learn English. Social demand from others such as parents, candidate, teachers, or the supervisor may be the reason for some of the students to learn English.

But whatever the motivation factors play an important role in learn a language, as quoted from the statement Gardner in Oxford(Oxford \& Scarcella, 1994). and from the statement Ihsan and Diem that the primary factor in the success of learning a language is motivation.(Ratnasari, 2015)

A study from Yuliyanti and Indrawati (Yulianti, 2014). about student motivation in choosing Education study program English at STAIN Syaikh Abdurrahman Siddiq Bangka Belitung the result shows that the factors extrinsic components that includes the hope of success, attitudes toward Americans and English as well as their culture, anxiety and strength is the most dominant factor.

Motivation factors will also affect student attitudes toward English language learning. During the discussion that has high motivation would potentially have a good attitude. And on the contrary students attorneys low would potentially have a negative attitude.

For teachers of foreign languages, especially English the potential of learning achieved by students will be increased at the time of the creation of a positive attitude and a high level of motivation. As an example of the ability of students to learn a foreign language can be influenced by their attitude toward the target language. The English teachers must recognize that there is a positive and negative attitude in the students learn a foreign language. Now the negative attitude can be changed through the use of teaching methods, materials and activities that vary. According to Adekunle, (Adekunle, 1995) this attitude play a major role in efforts to maintain the language.

When the majority during the STAIN Syaikh Abdurrahman Al-sidiq Bangka Belitung is a student of non-English. They are required to take English language courses from the beginning to the semester semester four that includes Intensive English language courses organized by the construction of the Bible (UBINSA Unit) and English language courses in their respective studies program.

Intensive English language teaching starts from the first semester beginning with the scope of the material that covers the four language skills namely, read (reading), Catching (Listening), Speak (Speaking), and write (Writing) and oriented parameters with the module or the same text book for each during the. Each Intensive English language class consisting of students non-English is derived from the program or any department of the different studies. Researchers assume that students from different study programs have interest and views as well as the skills of different English.

This research discusses some factors non-English student attitude toward the English language learning that includes their view of English, the source of the taste of the inconvenience that they have during the lesson, English ability students reviewed from the ability to communicate, fear makes an error grammar and language skills which is the most they want to learn (scrutinize, speak, reading and writing).

This research refers to Lin and Warden statement (Lin \& Warden, 1998) where they said that many of the English teachers in Asia to assume that all the students can be given the treatment, approach, and the type of teaching the same despite their different language ability. And also the discovery of the difference between the English language needs directions or a different field of study. Most of the students have the fear and have not pleasant feelings about the experience of learning English in the past.

\section{Discussion}

\section{The Attitude}

According to Robbins attitude is the statement evaluatif against the objects or events. This reflects the feelings of a person for something. While according to Breckler (Robbins \& Coulter, 2007) attitudes has three main components: awareness, perasaan, and perilaku. The belief that "discrimination is wrong" is a statement evaluatif. Opini This activity is a component kognitif of the attitude that determines the levels for the part that is more important than a -attitude afektifnya components. The feeling is a segment emosional or perasaan from an attitude and reflected in statements such as "I do not like John because he discriminated the minorities." Finally, feelings can cause the end result from perilaku. Components of the behavior of an attitude refers to a meaning to behave in a certain way toward someone or something. 
The attitude of a person has provide pattern in the behavior or actions of concerned (Ariani \& Sawitri, 2014) Krech and Crutchfield in (Ariani \& Sawitri, 2014)said that the behavior of a person will be colored or influenced by the attitude of the concerned. The experts social psychology provide understanding about the attitude that is a little different but basically all aimed to know prioritising a man. Walgito defines the attitude is an organization that contains the opinion, knowledge, sense of confidence about something that his nature is relatively constant on certain feelings and provide the basis for behave.(Robbins \& Coulter, 2007)

Thus the components of the attitude encompasses knowledge, the opinion of the mind, confidence and feelings and the tendency to act. Walgito also proposed that the attitude of the individual is usually consistent with one another and also in action consistent with one another. But for farmers attitudes and actions can be consistent when innovation is believed to provide the benefits and benefits, when an innovation does not provide benefits and his attitude can be changed on the other innovations. Change in attitude can directly or indirectly.

Change in attitude directly in the meaning of the existence of a direct relationship between the individual and the individual, between individuals and groups and no distinction group with the group. While through the relationship is not directly is through the media mass communication, both printed and electronic devices.

According to the Oxford Dictionary (Oxford \& Scarcella, 1994) should have (attitudes) is a way of thinking or behaving or in other words, the attitude is a way of thinking and berprilaku. While according to Ahmadi (Ahmadi, Pridmore, \& Fallahzadeh, 2004) attitude is:

a) Oriented toward the response: the attitude is a form of feeling, namely the feelings of support or favor (favourable) or feelings does not support (unfavourable) on an object.

b) Response preparedness oriented: the attitude is the readiness to react to an object with certain ways, when confronted with a stimulus package that requires a response.: a behavior patterns, tendenasi or the readiness to repress adjust themselves from the social situation which has been terkondisikan.

c) Oriented toward triadik scheme : the attitude is a constellation of cognitive components, affective, and konatif interacting with each other in understanding, feeling and behave toward an object in the surrounding environment.

In a simple way the attitude is defined as a simple expression of how we like or dislike toward some things.

According to Adekunle attitude is the feeling or opinion, like it or not like about something, someone, a group of people, objects, ideas, and so on. The Attitude have a major role in efforts to maintain the language in the community(Ahmadi et al., 2004).

Two of the theory related to the attitude is behavioris and mentalis. According to the theory of behavioris, attitude is the thing that can be observed that is visible from the behavior and how people respond to the social situation. While according to the theory of mentalis, attitude is something internal that was built in the individual and appears if there is a stimulus package.

There are several different attitude toward the Bible, namely:

Attitudes toward the ethnic cleansing of the speaker.

1. Attitudes toward the learning and teaching of the Bible.

2. Attitudes toward the variation say, accent and dialect norms.

3. The attitude toward language policy.

4. The attitude of the minority ethnolingiustic.

5. Attitudes toward the use of the Bible.

6. Attitudes toward the specific language.

7. The attitude to the type of language.

8. Attitudes toward genuine attendant explained foreign languages.

9. Attitudes toward indigenous languages.

According to Kridalaksana (Kridalaksana, 2001) language attitude is mental position or feelings toward their own language or the language of other people. In the Bahasa Indonesia said the attitude can refer to the form of the body, standing upright position, the behavior or movement of the rising, and action is taken based on the establishment of the belief or opinion) as a reaction to the existence of a thing or Genesis.

The attitude is a psychological phenomenon which usually termanifestasi in the form of action or behavior. The Attitude could not be observed directly. To observe the attitude can be seen through 
behavior, but the results of research shows that what appears in the behavior does not always show the attitude. So also on the contrary, the attitude of a person is not forever reflected in his behavior.

The situation and the process of formation of the attitude of the language is not far from the situation and the process of formation of the attitude in general. As is the case with the attitude and the attitude of the language is also a psychological events that cannot be observed directly. The attitude of languages can be observed through the behavior of language or the behavior of mr. But in this also applies to the terms that not every behavior of $\mathrm{mr}$ reflects the attitude of the language. So also on the contrary, attitude language does not forever reflected in the behavior of $\mathrm{mr}$. Between the Bible (langue Dibedakannya) and $\mathrm{Mr}$ (parole) according to de Saussure in Kridalaksana, then ketidaklangsungan relationship between the attitude of the language and behavior of $\mathrm{mr}$ becomes more of a more obvious. Language attitude tend to refer to the Bible as the system (langue), while the behavior of $\mathrm{mr}$ more tend to refer to the usage of the language in concrete steps (parole) (Fazio, 1990).

While for the teaching of foreign languages, Gebhard1 stated that students can gain more knowledge and experience of language with how to express their feelings and their attitudes in the target language. Thus the lesson materials should be more explore the feelings and personal attitude with the goal to teach the students to express themselves through the use of language which will reflect our personalities.

Now according to Brown, attitudes includes two aspects, namely cognitive and affective. These two aspects related with thoughts, feelings and emotion, attitudes lead the process of how the lesson. In this case, learning language demanding mastering foreign languages. The attitude was influenced by some of the things that parents, friends, and the environment. Therefore, the attitude is one of the part from the perception of a person against himself, other people and the culture where he lived (Brown, 2000)

Brown said that the positive attitude toward ourselves, against mother language groups and target language groups will be able to improve language ability. When the students have a positive attitude and perspective toward foreign language learning will generate positive attitude. But if the students have a negative attitude, this will make it fail to learn the target language. This is due to the attitude of many influenced by the experience so that the teaching of the Bible is good with through several strategies will be able to grow positive attitude for students.

As in the opinion of the Gardner, he said that the attitude is a component of the motivation which indicates that there is a combination of business and the desire to achieve something, terkhusus again in achieve success in learning to have a positive attitude toward language learning. Whatever the background of the motivation, then it is clear that the positive attitude is very important in studying the target language, which in this case is English (Gardner, 1985).

To be able to understand what is called the attitude Bible (Language Attitude) first be explained what is the attitude. The Attitude can refer to the form of the body, stood upright position, prioritizing or flexrising, and deeds or actions that are done based on the view (establishment, faith or opinion). As a reaction to the existence of a thing or Genesis. Behold, attitude is psychic phenomenon which usually termanifestasi in the form of action or prioritizing. But in many research is not always done physically is a reflection of the attitude of the inner person Chaer and Agustina (Chaer \& Agustina, 1995).

The attitude of the language on the generally regarded as prioritising against the Bible. The relationship between the language and pemertahanan attitude and language shift can be explained in terms of the introduction of prioritising or including that have the influence directly and indirectly for pemertahanan language. So important is the question of how the attitude of the language or a variety of different languages describe the views of people in different social characteristics describe the view that play a role in communication intra groups and between groups(Sembiring, n.d.).

The attitude of the language in the study sosiolinguistik refers in prioritising or actions that are done based on the view as a reaction to the existence of a phenomenon against the use of specific language by language proficiency. The language in a community may be different with other community how the language can be influenced by its use in accordance with different social characteristics. That is often a debate about the attitude of the language is in fact the attitude itself. Although widely known in the field of social psychology, there is no common agreement about the concept of the attitude itself. There are two different theoretical views about the attitude, namely the view of the mentalis and behaviris. The two views was always the focus of the theory and measurements done in research on the attitude of the individual and the attitude of the society B. U. Siregar.

In Chaer Fasold and Agustina proposed that in the examination of sosiolinguistik, devenisi language attitude is often expanded to include the attitudes toward proficiency of specific language proficiency. 
Pemerluasan devenisi that may provide the possibility that all kinds of prioritising related to the Bible, including attitudes toward pemertahanan languages can be explained.

Especially in relation to social psychology, for example Triandis in Chaer and Agustina says that the attitude is the readiness to react to a situation or events that faced. This readiness can refer to a situation or events that faced. This readiness can refer to the mental readiness or " paradigma attitude". The attitude is mental readiness or nerves, formed through experience that allotted toward or dynamic influence the reactions of someone against all objects and the situation regarding the attitude. While Lambert stated that the attitudes that consists of three components namely cognitive components, components apektif, and konatif components. Cognitive components refer to or related with the knowledge or a category called the process of thinking. Apektif components over issues of evaluation such as the good, the bad, love, or dislike toward something or a situation. If a person has a good sense of value or prefer to a situation, he is said to have a positive attitude. Otherwise called have a negative attitude. Konatif components regarding prioritizing or works as the decision of the end of the readiness of the reactive against a condition. Through this third component people usually try to guess how the attitude of a person toward a condition.

Based on the results of research about the experience of learning English at the elementary education before, students study program teaching is that most students do not have a fear of the English language learning in the previous levels of education. While the students study PGRA program is the most students have fear of English language learning in the previous levels of education.

Then the source of fear that most dominant experienced from the four studies program is the fear that not accurate readout. This is due to the difference in the readout system from each student is influenced by the language of their mother so that the students make a mistake in the inauguration.

While the source of the taste of pleasing others is how the instructions of the teachers in the class due to lack of students understanding of the material that is given by the teacher and the fear of the test because the English is still considered as subjects that difficult so that they fear facing trials, for example the fear of students in the face of the national examination in English language with the passing standards that continues to increase each year; and fear of making an error grammar (grammatical mistake). In addition to the source of the fear of external factors such as above, there are internal factors of students such as feeling lazy to learn, less interested in English, feel pessimistic and feel unable to learn English.

Regarding the sequence of language skills is the most important or favorite, students study program PGRA and PS want the sequence of the same language skills are listening to (listening), speak (speaking), read (reading), and write (writing). In accordance with the sequence of the skills of the most favorite, means that students tend to want to have the skills of catching along with hobby students listen to the song, news, radio is currently trends. While for students study program teaching wants the order language skills speak (speaking), catching (listening), read (reading), and write (writing) and sequence language skills writing (writing), read (reading), catching (listening), and speak (speaking). While for students study program BPI wrote (writing), read (reading), catching (listening), and speak (speaking) is the most favorite.

In accordance with the sequence of the skills of the most favorite, means that students tend to want to have the skills of catching (listening) along with hobby students listen to the song, news, radio that is the current trend of the sequence of the next is speaking (speaking) where they consider will be more confident and able to socialize with easy if can speak English in the association. They tend to combine or replace specific terms of their everyday language to English. While reading (reading and writing (writing) is the language skills that most deals are considered important by the students because of the two skills or expertise requires the mastery of vocabulary is more, enough exercise time and require more complex skills and as known that reading and writing habit is still low.

While on the attitude of the student non-English to English language learning in the STAIN SAS Babel, more than half of the total respondents argue that the ability to communicate with foreigners in English is not the basic objectives of learning English. In other words, they passively in the use of English and are categorized as Passive English Learner. This is also related to their career that may not be using English actively. Although based on the results of the questionnaire $41,4 \%$ students argue that speaking is language skills that most they want to learn.

For the students of non-English at STAIN SAS Babel, basic objectives in learn English is not just to communicate or speak only, but might have to be able to read or understand the literature or books of the English language in accordance with the science of them and their career in the future. This is in line with the answer from the results of the questionnaire that the skills of reading is the next skills they want to learn as much as $33,6 \%$. This is also supported by the fact that $49,6 \%$ from they only want to be able to read only. Followed by the writing skills and listening to the answer in a neutral by students who tend to be not too want to learn both the skills. This is supported by the statement that they do not agree and do 
not want to have the ability to listen to and the ability to understand English as much as $43,1 \%$, they really want to learn skills to speak and want to focus on reading skills but the fact that they do not want to learn English in the English speaking environment.

While for the method of learning English, students non-English at STAIN SAS Babel does not want to learn English through the translation of the grammar and vocabulary translation with the fact as much as $47.4 \%$. Students do not want to if asked to translate the material in English and did not want to learn or search for vocabulary through the translation to broaden them. From the results of the questionnaire also obtained students feel afraid to make mistakes in grammar when speaking in English because of the lack of mastery of grammar and also the lack of treasury vocabulary in English.

\section{Conclude}

Based on the results of research and the calculation of the English language learning in elementary education(Flood, Lapp, Squire, \& Jensen, 2003) before, then the researchers conclude that:

1. Students of non-English STAIN SAS Babel by the majority does not have a fear of the English language learning in the previous levels of education.

2. Students of non-English STAIN SAS Babel who have a fear of the English language learning in elementary education previously caused by fear of the readout inaccurate, how the instructions of the teachers in the classroom who do not understand the fear of the test because the English is still considered as subjects that difficult, fear make an error grammar (grammatical mistake), the existence of lazy to learn, less interested in English, feel pessimistic and feel unable to learn English.

3. Students of non-English STAIN SAS Babel wants the order language skills such as listening to (listening), speak (speaking), read (reading), and write (writing) as their favorite skills.

Based on the results of research and calculations about attitudes toward the English language learning (Mintz, Dobson, \& Romney, 2003)in the STAIN SAS Babel, researchers conclude that:

1. Students of non-English STAIN SAS Babel holds that the ability to communicate with foreigners in English is not the basic objectives of learning English.

2. Students of non-English STAIN SAS Babel holds that speak is the language skills that most they want to learn.

3. Students of non-English STAIN SAS Babel holds that the skills of reading is the next skills they want to learn and according to them the basic objectives in learn English is not just to communicate or speak only, but also to be able to read or understand the literature or books of the English language in accordance with the science of them and their career in the future.

4. Students of non-English STAIN SAS Babel tend not too want to learn writing skills (writing) and listens to the (listening).

5. Students of non-English STAIN SAS Babel want to learn skills to speak and want to focus on reading skills but the fact that they do not want to learn English in the English speaking environment.

6. Students of non-English STAIN SAS Babel did not want to if asked to translate the material in English and did not want to learn or search for vocabulary through the translation to broaden them.

7. Students of non-English STAIN SAS Babel feel afraid to make mistakes in grammar when speaking in English

\section{Reference}

Adekunle, M. (1995). English in Nigeria: Attitudes, policy and communicative realities. Bamgbose et Al (Eds.) New English: A West African Perspective Ibadan: Mosuro Publishers and Book Sellers.

Ahmadi, J., Pridmore, S., \& Fallahzadeh, M. (2004). Neurotic scores in a sample of medical students. Ger J Psychiatry, 7(1), 51-55.

Ariani, R. T., \& Sawitri, D. R. (2014). Hubungan antara persepsi terhadap pola asuh orang tua otoriter dengan agresivitas pada remaja. Empati, 3(4), 492-502.

Brock-Utne, B. (2001). Education for All-in whose language? Oxford Review of Education, 27(1), $115-134$.

Brown, H. D. (2000). Principles of language learning and teaching.

Butler, Y. G., \& Iino, M. (2005). Current Japanese reforms in English language education: The 2003 
"action plan." Language Policy, 4(1), 25-45.

Byram, M., \& Hu, A. (2013). Routledge encyclopedia of language teaching and learning. Routledge.

Chaer, A., \& Agustina, L. (1995). Sosiolinguistik: Suatu Pengantar. Rineka Cipta.

Echevarria, J., Short, D., \& Powers, K. (2006). School reform and standards-based education: A model for English-language learners. The Journal of Educational Research, 99(4), 195-211.

Fazio, R. H. (1990). Multiple processes by which attitudes guide behavior: The MODE model as an integrative framework. In Advances in experimental social psychology (Vol. 23, pp. 75-109). Elsevier.

Flood, J., Lapp, D., Squire, J. R., \& Jensen, J. M. (2003). Handbook of research on teaching the English language arts. ERIC.

Gardner, R. C. (1985). Social psychology and second language learning: The role of attitudes and motivation. Arnold.

Hatch, J. A. (2002). Doing qualitative research in education settings. Suny Press.

Helsby, G., \& McCulloch, G. (2002). Teacher professionalism and curriculum control. In Teachers' professional lives (pp. 64-82). Routledge.

Kridalaksana, H. (2001). Kamus Linguistik edisi ketiga. Jakarta: PT Gramedia Pustaka Utama.

Lin, H.-J., \& Warden, C. A. (1998). Different attitudes among non-English major EFL students. The Internet TESL Journal, 4(10), 1-9.

Mintz, A. R., Dobson, K. S., \& Romney, D. M. (2003). Insight in schizophrenia: a meta-analysis. Schizophrenia Research, 61(1), 75-88.

Oxford, R. L., \& Scarcella, R. C. (1994). Second language vocabulary learning among adults: State of the art in vocabulary instruction. System, 22(2), 231-243.

Ratnasari, D. (2015). MOTIVATION OF EFL STUDENTS AT TERTIARY LEVEL. The Journal of English Literacy Education: The Teaching and Learning of English as a Foreign Language, 2(1), 24-32.

Robbins, S. P., \& Coulter, M. (2007). Principles of management. Translated by Seyyed Mohammad Arabi and Mohammed Ali Hamid Rafiee and Behrouz Asrari Ershad, Fourth Edition, Tehran: Office of Cultural Studies.

Sembiring, S. (n.d.). Sikap Bahasa Penutur Bahasa Indonesia.

Yulianti, F. (2014). Hubungan antara Karakteristik, Tingkat Pengetahuan dan Dukungan Keluarga terhadap Pemberian Asi Eksklusif di Wilayah Kerja Puskesmas Siantan Hulu Kecamatan Pontianak Utara Tahun 2014. Jurnal Mahasiswa PSPD FK Universitas Tanjungpura, 1(1). 